\title{
On the Classification of Seed-Leaves.
}

\author{
BY \\ T. G. HILL \\ AND \\ E. DE FRAINE.
}

N a highly interesting study of Syncotyly and Schizocotyly, Mr. Compton, ${ }^{1}$ 1 whilst in agreement with our general conclusions, ${ }^{2}$ adversely criticizes us with regard to what we have termed 'subsidiary cotyledons'.

The classification of cotyledons was a by-way in our main work on seedling-structure, and one to which we do not attach a vast amount of importance; but since Mr. Compton, who has much first-hand knowledge of the subject-matter, finds difficulties in understanding our position, it is not unlikely that others also will find difficulties; hence it appears desirable to write a few words in reply.

It was found, in our work referred to above, that although the seedleaves, more especially of the polycotylous Gymnosperms, might be exactly similar externally, the behaviour of their vascular bundles in the transition phenomena might be very different.

I. In some cases the vascular strand of a cotyledon gave rise to one pole of the root-structure.

2. In other instances, the vascular bundles of two adjacent cotyledons gave origin to one pole of the root-structure.

3. And in some examples, the trace of a seed-leaf played no part in the transition phenomena, but joined on to any adjacent vascular tissue in no definite fashion.

From the constant occurrence of these phenomena, the seed-leaves were respectively divided into three classes: (i) whole cotyledons, (ii) halfcotyledons, and (iii) subsidiary cotyledons.

We expressly stated that this classification was based on the behaviour of the seed-leaf traces in the transition region. ${ }^{3}$ Whether we were justified

1 Compton, R. H. : An Anatomical Study of Syncotyly and Schizocotyly. Ann. Bot., I9I3, vol. xxvii, p. 793 .

2 Hill, T. G., and de Fraine, E. : On the Seedling Structure of Gymnosperms. Ann. Bot., 1908, vol. xxii, p. 689 ; 1909, vol. xxiii, p. I89.

${ }^{3}$ Hill and de Fraine: Seedling Structure of Gymnosperms. II. Ann. Bot., 1909, vol. xxiii, p. 221 .

[Annals of Botany, Vo1. XXVIII. No. CX. April, 1914.] 
'in arguing from anatomy to morphology in this matter' is doubtless a matter of individual opinion; it is certainly a classification which is remarkable in the fact that it does not break down when applied, and further, it may be remarked that anatomy is frequently a very valuable aid in determining morphological status.

Mr. Compton cites Cupressus torulosa Series C, Abies sibirica Series B, and Abies amabilis as examples illustrating that the above classification, even when restricted solely to the vascular strands, cannot be applied strictly. We have referred to our written descriptions of the transition phenomena in these plants, and quite fail to see any difficulty whatever in the interpretation with regard to the first and last named plant. The instance of Abies sibirica presented some difficulties which are fully considered and met in the paper. ${ }^{1}$ Of the large number of polycotylous Gymnosperm seedlings examined, this particular example, Abies sibirica, is one of a very few, if not the only one, in which the interpretation of the value of the cotyledons did not assert itself obviously. There is much to be said for a classification which is so generally applicable; a conception is not, we think, to be condemned because one particular example does not at first sight appear to fit.

In further support of his contention, Mr. Compton cites his observations on Phacelia tanacetifolia. ${ }^{2}$ No illustrations are given of the vascular rearrangements in this plant, but from his account we should say that our classification finds considerable support.

It does not appear necessary to examine in detail all the examples of this plant examined by Mr. Compton; two, however, may be dealt with at some little length.

Hemitricotyl A: In this seedling there was one entire and one bifurcated cotyledon. The vascular bundle of the former gave origin to one pole of the diarch root, whilst the two bundles, which did not fuse together before entering the hypocotyl, from the deeply forked cotyledon, together formed the other pole of the diarch root-structure. The interpretation is clearthere were two whole cotyledons, one of which was so deeply split as almost to form two half-cotyledons.

In the case of Tricotyl B there were three cotyledons, the bundles of which divided into two and gave rise to a triarch root-structure. At a lower level the triarch arrangement became reduced to diarch. Mr. Compton, who traces the vascular changes from the root to the seed-leaves, calls this the 'diarch-triarch' structure. This method of increase in the number of protoxylems is not uncommon among tricotyls. It is not 'the method followed by the vascular bundles of so-called subsidiary cotyledons in Coniferae', as Mr. Compton states. According to our reading of the facts, there were no subsidiary cotyledons in this example of Phacelia: there 
were three whole cotyledons, the vascular bundles of which gave rise to a triarch root-structure which subsequently became reduced to diarch, a phenomenon not at all uncommon in the Coniferae.

With regard to the other seedlings of Phacelia, the following analysis is perfectly obvious from Mr. Compton's description.

Tricotyl C and Hemitetracotyl D. Three whole cotyledons. Rootstructure triarch throughout.

Tetracotyl E. Four whole cotyledons. Root-structure tetrarch above, but successively reduced at lower levels to triarch and diarch.

It is clear that Mr. Compton quite misunderstands our conception, and this, in part, is possibly due to the fact that he worked from below upwards, whilst we, in common with most other investigators of seedling anatomy in this country, worked from the cotyledons downwards. This appears from the following quotation: ${ }^{1}$

' The most striking feature in the schizocotyls of Phacelia is the fact that the vascular strands [presumably of the root, below the collar] do not split to correspond with the split of the cotyledons. In all cases (except two, where the division occurred in the lamina) the number of xylem bundles is increased by the addition of new ones, not by the division of old. On tracing the strands from above downwards, we may say that in these cases the traces of certain cotyledons or half-cotyledons do not contribute to the structure of the root, but die out in the hypocotyl. This is the characteristic ${ }^{2}$ of "subsidiary cotyledons" - a category of plant-members which apparently cannot be maintained.'

In all our work, the first organization of a root-structure, whether it occurred high up or low down in the hypocotyl or below the collar, was taken as a factor in our classification.

This appeared the obvious course to take, for the fact that the number of poles might be altered at a lower level results in chaos, as Mr. Compton has found. If the structure of the root at a lower level is to be taken, what particular level is to be selected, and what is to guide us in our selection? It is not at all infrequent, especially when the number of cotyledons varies, that the number of poles in a root, with the exception of diarch roots, becomes reduced and sometimes increased as we pass towards the apex. For instance, a pentarch root might show a reduction to tetrarch and finally to triarch just above the apex; it is possible that if the seedling had been allowed to grow for a week or so longer and then examined, a further reduction to diarchy might be shown.

The difficulty could be overcome by referring the structures in question to a diarch organization, on the assumption that this is primitive; and this no doubt would be excellent philosophy, but it does not appeal to us as science.

${ }^{1}$ Loc. cit., p. 8 I 2 .

2 As we have already remarked, it is not. 
Mr. Compton correlates the final root-structure with the cotyledonary bundles, and takes no count of the root-structure which first results from the arrangement of the seed-leaf traces; we do exactly the reverse, and it appears that this is the cause of the misconception.

The polycotylous condition is an heritable quality, and since it appears to be generally, but not universally, agreed that the primitive condition was dicotyledonous, the presence of many seed-leaves, many of which may be whole cotyledons, in a seedling has to be accounted for.

This is, of course, a difficult matter, since we cannot 'have our cake and eat it'; in other words, we cannot dissect a seedling and also examine its progeny.

It appears not improbable that in the course of descent the half or the subsidiary cotyledons of an ancestor should become of increasing importance in succeeding generations until they became whole or half-cotyledons respectively.

This was our meaning in saying that a half-cotyledon could arise by the 'promotion' of a subsidiary cotyledon. The same goal can be arrived at in different ways, so that, for us, it is not unthinkable that a 'halfcotyledon' is sometimes the half of a whole cotyledon, whilst in other instances it represents a promoted subsidiary cotyledon. ${ }^{1}$

In view of Mr. Compton's account ${ }^{2}$ of the 'Theories of the Anatomical Transition from Root to Stem', which is an admirable exposition of the different views of the various schools of anatomists especially in relation to seedling structure, it would appear to be unnecessary to consider in detail M. Dauphiné's criticism ${ }^{3}$ of our work on the Centrospermae. ${ }^{4}$ It may, however, be remarked that this particular investigation was a continuation of our work on seedling anatomy, carried out from the phylogenetic point of view and commenced some thirteen years ago; in which investigation we, in common with most other British workers in the same field, considered the vascular tissues in the gross. In writing the paper on the Centrosperms we fully recognized the high value of M. Chauveaud's work on the same group, but we did not think it desirable to make reference to it since such reference, to be of any value, would have involved a long consideration of the views of the different schools of thought and would have tended to obscure our main line of work.

University College, LONDON.

1 See Hill and de Fraine: Ann. Bot., I909, vol. xxiii, p. 222.

${ }^{2}$ New Phyt., 191 2, vol. xii, p. I3.

3 A. Dauphiné : Sur le développement de l'appareil conducteur chez quelques Centrospermées. Bull. Soc. Bot. France, 19I 3, vol. xiii, p. 3 I 2.

${ }^{4}$ Hill and de Fraine : On the Seedling Structure of Certain Centrospermae. Ann. Bot., I9I2, vol. xxvi, p. I75. 


\section{$2 \mathrm{BHL}$ Biodiversity Heritage Library}

Hill, T. G. and De Fraine, E. 1914. "On the classification of seed-leaves." Annals of botany 28, 359-362. https://doi.org/10.1093/oxfordjournals.aob.a089511.

View This Item Online: https://www.biodiversitylibrary.org/item/236856

DOI: https://doi.org/10.1093/oxfordjournals.aob.a089511

Permalink: https://www.biodiversitylibrary.org/partpdf/320029

\section{Holding Institution}

Smithsonian Libraries

\section{Sponsored by}

Biodiversity Heritage Library

\section{Copyright \& Reuse}

Copyright Status: Not in copyright. The BHL knows of no copyright restrictions on this item.

This document was created from content at the Biodiversity Heritage Library, the world's largest open access digital library for biodiversity literature and archives. Visit BHL at https://www.biodiversitylibrary.org. 